Journal Home Page:

http://perlinguam.journals.ac.za

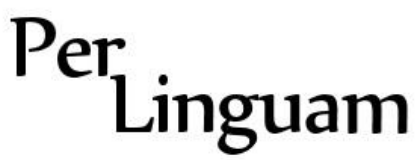

A Journal for Language Learning Tydskrif vir Taalaanleer

\title{
CODE MESHING: ONLINE BILINGUAL TUTORING IN HIGHER EDUCATION
}

\author{
Thoko Batyi, Nelson Mandela Metropolitan University
}

Students' academic writing literacies are required to express their knowledge, as academic writing is the common mode of assessment in higher education. 28 isiXhosaspeaking first-year diploma students, who failed an academic literacies admission test evaluating the level of their academic writing literacies in the Business faculty, participated once a week over a period of eight months in a course including the practice of code meshing. In the June and November Tourism Communication tests, which also evaluated their academic writing literacies, there was a significant difference in the mean scores when compared to the admission test in the Business faculty. Their academic writing had also improved, according to their assignment marks. The researcher in this project provides evidence that code meshing as a bi/multilingual strategy could be used to improve academic writing literacies in students.

\section{INTRODUCTION}

Although South Africa is democratic and supposedly experiences equal use of all 11 languages, English is dominant in official domains, particularly in higher education. Students in South African higher education institutions are from diverse language backgrounds, and mix languages outside classrooms, but their multilingual repertoires are seemingly not used for learning in academic contexts. Instead, language policies in these institutions mandate English as the language of teaching and learning. Ruiz (1984) notes that the primary language of students can be used as a resource when learning another language. Thus, the repertoires of multilingual students can help them to improve their academic literacies, including academic writing. In this study, an online space was created for students to respond in both English and isiXhosa to prompts posted by both their Tourism lecturer and their Communication tutor.

\section{THEORETICAL FRAMEWORK}

Translanguaging is regarded as a naturally occurring phenomenon amongst multilinguals, particularly in informal contexts. Canagarajah uses the term translanguaging for the general communicative competence of multilinguals and 'code meshing' for translanguaging in texts (Canagarajah, 2011: 403). Educators need to know how intuitive communicative strategies like translanguaging could be developed for use in academic contexts (Canagarajah, 2011: 401), to improve learning.

Code meshing (Canagarajah, 2007a) differs from code-switching, as it goes beyond mixing languages and varieties of languages. In code meshing all discourses are active and integrated into a coherent sociolinguistic space. Bilingual students use their languages or varieties at the same time. There is no rule to change languages at lexical or syntactic level. The code-meshed languages form one structure, which may only be acceptable in certain spaces (for example, informal academic spaces like tutorials). Code 
meshing can be seen as the transfer to academic environments (specifically writing) of language alternation. This often happens intuitively with multilinguals, when they negotiate meanings and identities in informal spaces, and is 'used surreptitiously behind the backs of the teachers in classes that proscribe language mixing' Canagarajah (2011: 401).

The term code meshing, can also be applied to combining local, vernacular, colloquial, world dialects of English with standard written English in formal assignments and in everyday conversation in an attempt to embrace our globalised and diverse world (Canagarajah, 2006: 586). Canagarajah says it is 'a strategy for merging local varieties with the standard written English in a move towards gradually pluralising academic writing and developing multilingual competence' (2006: 586). When the varieties of English are merged with Standard English, a space is created for pluralising academic writing. In addition, cultural and ideological influences on the writing of students are no longer regarded as errors, but as rhetorical independence and critical thinking (Canagarajah, 2006: 609).

Code meshing in a private space, such as the tutorial-linked, online space in this study, provides students with opportunities to integrate languages flexibly. Communication will not stop because of low competence in one language (for example, English), as students will change to another when experiencing problems. In Canagarajah's (2011) study, Bhutainah, the Arabian undergraduate student, used translanguaging while drafting an essay. She gained deeper understanding of herself as a writer, since her identity in her language and comfort in its use enabled her to change her ideas randomly while writing. Velasco \& Garcia (2014:6) also suggest that translanguaging is a self-regulating mechanism which bilingual learners can engage, to help them achieve their writing goals.

Translanguaging in informal social spaces is not taught or monitored; it happens intuitively and naturally. The same strategy can be used with minimal pedagogical effort in academic spaces (Canagarajah, 2011: 402). It can be applied and taught strategically. Senior students facilitating learning in tutorials can use translanguaging to enhance learning. Students can learn their disciplinary literacies from others using translanguaging and code meshing, instead of relying solely on the formal lecture space. They could come to lectures better prepared after interacting with others in a more social situation.

Canagarajah (2011: 403) believes that code-switching treats language alternation as a bilingual competence that implies switching between two different systems, while code meshing and translanguaging treat languages as part of a single integrated system. In code meshing, communicative modes and diverse symbol systems can be mixed. Hence, the three phenomena (code-switching, translanguaging and code meshing) can function differently in different contexts.

Martin-Jones and Jones (2000: 7), emphasise that multilingual students draw from their 'multilingual literacies' when they learn. So, during code meshing, multilingual students may draw from their multilingual literacies when writing. The multilingual literacies have equal value during communication in informal contexts. However, this does not happen during communication in academic contexts, particularly during writing. 
Hornberger's (2004: 158) 'continua of biliteracy' illustrate the way in which writing can be included in different contexts:

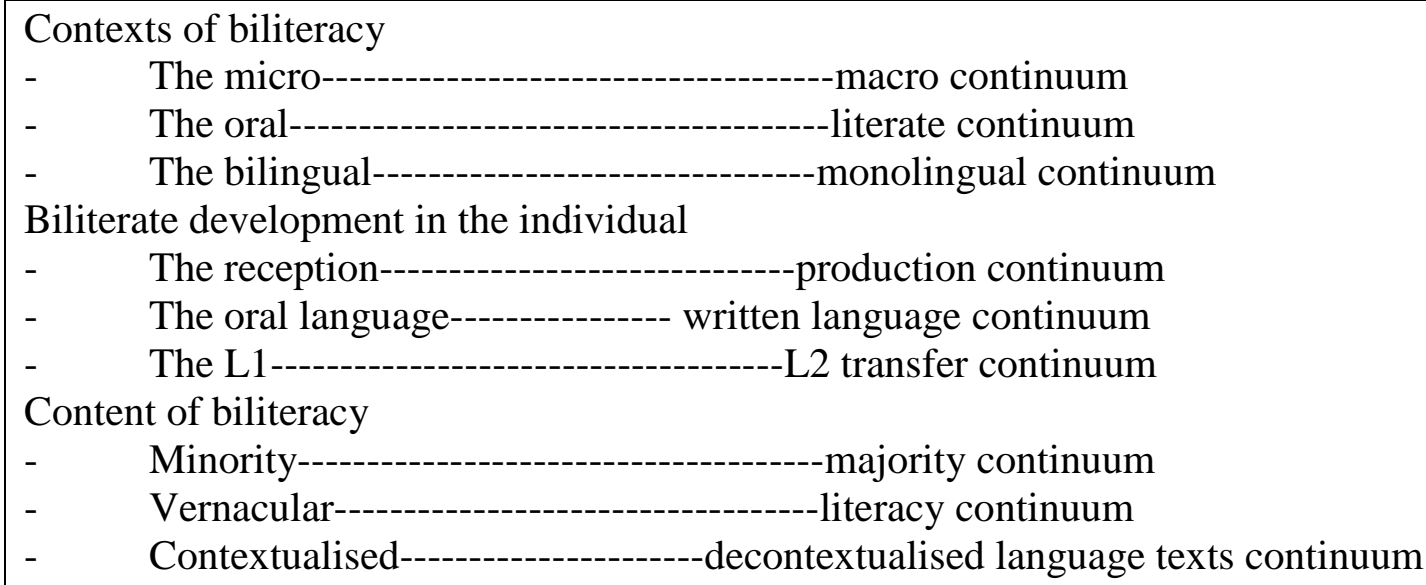

Figure 1: Hornberger (2004: 158)

According to Hornberger (2004: 158), the left represents the less powerful, while the right represents the more powerful end of the continuum. This shows that writing modes and a dominant L2 are privileged over oral modes and minoritised L1 because of differences in power relations, yet biliteracy is better obtained when learners can draw on all points of the continua (Garcia, Bartlett \& Kleifgen, 2006: 9). Because of this power on the right side of the continua, students participating in this study were hesitant to mix languages during code-meshed writing, although they were allowed to do so in the tutorial.

According to Cenoz and Gorter (2011: 360), since languages are traditionally taught and learned separately, competencies would also increase separately, something which Cenoz (2009) calls 'monolingual focus':

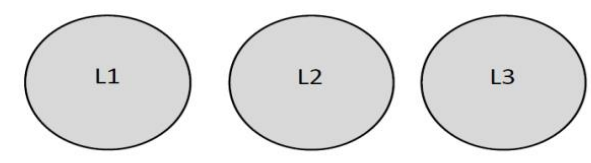

Traditional Approach

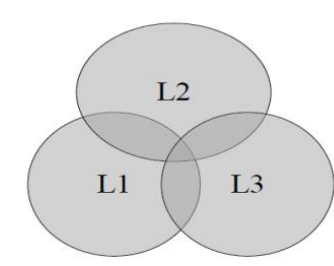

Focus on Multilingualism

Figure 2: Traditional approach and Multilingualism focus.

Today, however, the focus on multilingualism 'looks at the whole linguistic repertoire and the relationship between languages when conducting research, teaching or assessing different languages' (Cenoz \& Gorter, 2011: 360). These linguists argue that translanguaging, as a pedagogical strategy, becomes easy and commonalities can be explored if all languages are allowed to be available either for learning content or another language together, as they can support and reinforce each other. Ideally learners can alternate languages in academic contexts 
and understand the relationship between them for enhanced learning of the target language. In a holistic approach to multilingualism, students use language according to their needs (Cenoz \& Gorter, 2011: 340). If they find one language too difficult to express an idea, they switch to another without any distortions to the message or argument. The language competence of multilingual learners cannot be compared to that of the monolingual English native speaker, as the whole cognition of the multilingual is positively affected when they learn a second or third language (Cenoz \& Gorter, 2011: 340).

Code meshing can provide quiet students in the classroom with an opportunity to voice their ideas, as their silence may stem from fear of incorrect use of a second language. In code meshing these students can formulate their responses at their own pace, with time to revise in their languages of choice. These students could also interact and learn from communities of students speaking varieties of English, instead of the 'native English community' imposed by the teacher in the classroom (Canagarajah 2006: 591). Most isiXhosa-speaking students do not find learning or writing in English easy (Paxton 2009: 356), but code meshing can enable these students to express their knowledge in both languages without having to translate.

Although there are fascinating studies about translanguaging outside classrooms, (Makalela 2013), such practices have not been developed as pedagogical strategies, thus scholars are urged to do this kind of research (Creese \& Blackledge, 2010). This study is an attempt to develop code meshing as a pedagogical strategy, used to improve the academic writing of multilingual students.

\section{METHODOLOGY}

The researcher wished to investigate the usefulness of code meshing as a strategy for improving academic writing of students in the Tourism Communication tutorial. An online space was created for students to code mesh and data were collected from their discussions. This strategy was chosen as a tool although the researcher knew that translanguaging in literacy was more challenging than in speaking (Canagarajah, 2011: 402). This online space allowed participants to practise translanguaging while discussing or answering questions on Tourism. Students accessed this space in their own time and their interaction provided them with an opportunity to improve their competence in the languages forming their repertoires. It helped them to learn from others how to negotiate meaning and style when writing about Tourism in both or all of their languages.

The researcher worked in collaboration with the Tourism lecturer, from the same language background as the participants and the tutor. Students were taught how to access the space online. Then the tutor gave them Tourism texts assigned for reading, both in the tutorial and in their own time. The tutor posted questions posed by the Tourism lecturer for students to answer and/or discuss using code meshing. Questions were to be posted weekly from March to November. However, only 10 questions were posed owing to the slow pace of the students in answering them. The responses of students were printed and analysed at the end of the year. The researcher hoped to see the academic literacies gradually improving in the student responses. She hoped to determine whether the students understood the texts they had to read and the questions. That would be demonstrated through relevance of content, accurate use of terms and 
concepts and clear arguments in their responses. Relevance of their discussions was compared with their arguments in assignments (about the same Tourism topics); and their use of terminology was compared in their June and November tests.

The student discussions online were responses to questions from the Tourism lecturer on reading texts and lectures. Responses were either in English only or in both English and isiXhosa. No responses were in isiXhosa only. To analyse content, the responses to each of the ten prompts were printed and their datawere analysed through coding (Bryman, 2009: 298). A coding manual, consisting of a coding schedule, was designed. The coding schedule included the number of the prompt/question, day, month, year, gender of the student, number of responses for the prompt, number of students using English only or both languages, responses with relevant content, and responses with irrelevant answers.

\section{RESULTS}

Table 1 below shows the coding schedule and the coding manual.

\begin{tabular}{|c|c|c|c|c|c|c|c|c|}
\hline $\begin{array}{l}\text { Prompt } \\
\text { No. }\end{array}$ & Day & Month & Year & Gender & $\begin{array}{l}\text { No. of } \\
\text { responses }\end{array}$ & $\begin{array}{l}\text { Languages } \\
\text { used }\end{array}$ & $\begin{array}{l}\text { Rele- } \\
\text { vant } \\
\text { Content }\end{array}$ & $\begin{array}{l}\text { Irrele- } \\
\text { vant } \\
\text { Con- } \\
\text { tent }\end{array}$ \\
\hline 1 & 2 & 4 & 12 & $\begin{array}{lc}\text { Male } \quad 8 \\
\text { Female } & 10\end{array}$ & 18 & $\begin{array}{ll}\text { English } & 94 \% \\
\text { Both } & 11 \% \\
\end{array}$ & 13 & 5 \\
\hline 2 & 18 & 4 & 12 & $\begin{array}{ll}\text { Male } & 4 \\
\text { Female } & 10\end{array}$ & 14 & $\begin{array}{ll}\text { English } & 100 \% \\
\text { Both } & 0 \%\end{array}$ & 8 & 6 \\
\hline 3 & 2 & 5 & 12 & $\begin{array}{lc}\text { Male } \quad 7 \\
\text { Female } 10\end{array}$ & 17 & $\begin{array}{ll}\text { English } & 47 \% \\
\text { Both } & 52 \%\end{array}$ & 12 & 5 \\
\hline 4 & 17 & 5 & 12 & $\begin{array}{ll}\text { Male } & 5 \\
\text { Female } & 6\end{array}$ & 11 & $\begin{array}{ll}\text { English } & 45 \% \\
\text { Both } & 54 \%\end{array}$ & 8 & 3 \\
\hline 5 & 16 & 8 & 12 & $\begin{array}{ll}\text { Male } & 12 \\
\text { Female } & 7 \\
\end{array}$ & 19 & $\begin{array}{ll}\text { English } & 36 \% \\
\text { Both } & 63 \% \\
\end{array}$ & 15 & 4 \\
\hline 6 & 30 & 8 & 12 & $\begin{array}{lr}\text { Male } & 12 \\
\text { Female } & 14\end{array}$ & 26 & $\begin{array}{ll}\text { English } & 38 \% \\
\text { Both } & 61 \%\end{array}$ & 20 & 6 \\
\hline 7 & 26 & 9 & 12 & $\begin{array}{ll}\text { Male } 8 \\
\text { Female } 10\end{array}$ & 18 & $\begin{array}{ll}\text { English } & 11 \% \\
\text { Both } & 88 \% \\
\end{array}$ & 14 & 4 \\
\hline 8 & 17 & 10 & 12 & $\begin{array}{ll}\text { Male } & 7 \\
\text { Female } & 6 \\
\end{array}$ & 13 & $\begin{array}{ll}\text { English } & 7 \% \\
\text { Both } & 92 \% \\
\end{array}$ & 10 & 3 \\
\hline 9 & 24 & 10 & 12 & $\begin{array}{lr}\text { Male } 7 \\
\text { Female } 8\end{array}$ & 15 & $\begin{array}{ll}\text { English } & 6 \% \\
\text { Both } & 93 \%\end{array}$ & 15 & 0 \\
\hline 10 & 7 & 11 & 12 & $\begin{array}{l}\text { Male } 6 \\
\text { Female } 4\end{array}$ & 10 & $\begin{array}{ll}\text { English } & 20 \% \\
\text { Both } & 80 \%\end{array}$ & 10 & 0 \\
\hline
\end{tabular}

Table 1: Code-meshing results

According to the coding manual, Prompt One was posted on 2 April 2012. 18 of 28 students in the tutorial responded (8 male and 10 female students). Of the 18 students who responded, 17 used one language (English) and one used two languages (English and isiXhosa) to respond. Thirteen (13) responses were relevant and five were irrelevant. Hence, answers in 13 responses answered the question in Prompt one, while answers in 
five responses were incorrect. In Prompts one and two, students were reluctant to code mesh. By the time students were responding to Prompt nine and ten, they had learned code meshing. They mixed languages while discussing the content, arguing or defining concepts. Some students mixed languages at syntactic level while others mixed them at lexical and paragraph level. Students could mix languages at any level. They could also use one language more than the other. The majority code meshed and all their responses were approved as relevant to the Tourism topic. Students who participated in code meshing and used both English and isiXhosa to respond to prompts, saw both their assignment and test marks improving during the year. See figure 3 for the test results.

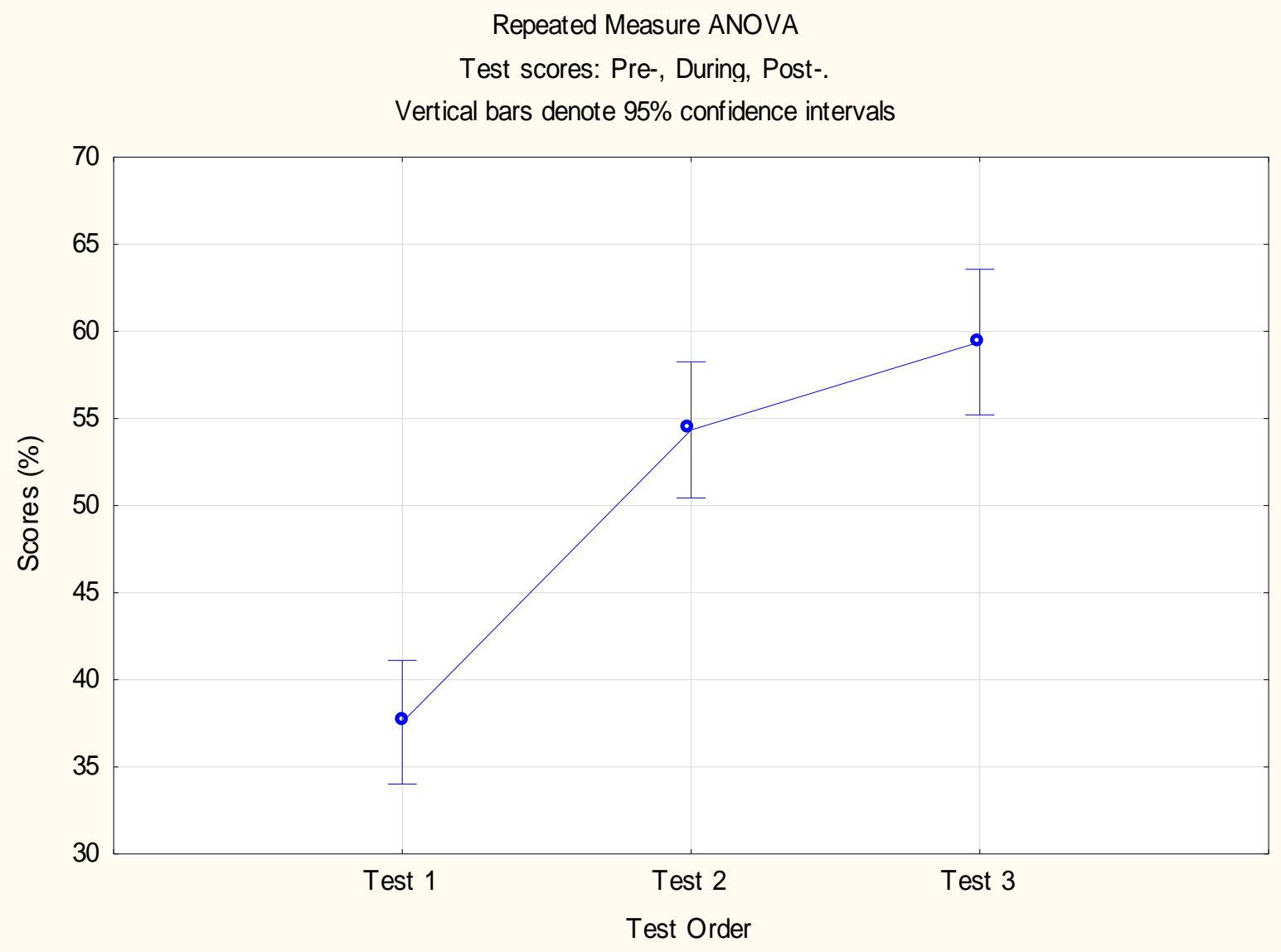

Figure 3: Test results after code meshing: (95\% confidence interval and 5\% significance level)

\section{DISCUSSION OF RESULTS}

Quantitative results from tests written by participants after intervention through code meshing show that the use of code meshing for teaching and learning led to improvement in the academic literacies of students, including their academic writing. When participants started the tutorial at the beginning of 2012, their literacy test scores (the EPA) were below $50 \%$, as indicated in Test 1 above, with a mean score of 37.57 . However, by June in Test 2, the mean score was at 54.35, and in November, in Test 3, the mean score was 59.39. Although other factors might have contributed to the improvement of the mean scores and their academic literacies inside and outside the Tourism Communication tutorial, students confirmed in the questionnaire and in the interview that code meshing helped them. For example, of 26 students who answered the 
questionnaire $69 \%$ were in favour of code meshing. They explained that code meshing provided them with a platform to apply the newly-learned Tourism terms and concepts; gave them an opportunity to learn how others argue certain Tourism topics; and they learned new terms and concepts from the responses of others online. The Tourism lecturer noted that students who regularly applied code meshing were able to apply the Tourism concepts accurately in class and they performed better than those who did not participate.

All the tests investigated the level of student academic literacies and were set by the same examiner, not the researcher, which confirms a similar style of questioning. The last two tests could have been more challenging, as they included referencing as an academic writing literacy; however, students' marks in both tests improved.

Students reported being in favour of code meshing, although one who had not learned isiXhosa at school struggled to code mesh in English and isiXhosa and did not participate, but read other student responses to revise for tests. Student answers to the prompts were informed by reading. This contributed to the improvement of their writing. They learned from each other and their regular participation provided them with practice. Their assignments also confirmed the improvement of their academic writing, as they learned how to write arguments and to use Tourism terms and concepts in discussions in the code-meshing forum.

This reveals that alternating languages during teaching and learning is an effective pedagogical practice (Garcia \& Leiva, 2014: 199). Teaching students to mesh isiXhosa and English in their responses to Tourism prompts, was an attempt to contribute to studies that develop the intuitive communicative strategies multilinguals display in everyday life in academic contexts (Canagarajah, 2011: 401). In this study students were provided with a safe space to adopt their multilingual repertoires for learning (Canagarajah, 2011: 402). If multilingualism is what the environment enables (Blommaert et al. (2005: 197), students were provided with an environment that enabled their multilingualism.

While students were slow in learning to use their own language (isiXhosa) for discussing academic content online, (see code meshing results for Prompt one andtwo), they did learn to use their language as a resource in following responses. The fact that 17 of 18 students responded in English only while the instruction was clear that they had to use both their languages, means that translanguaging does not come naturally in academic contexts, particularly in writing. Thus, Canagarajah's (2011: 402) practice-based model of translanguaging is confirmed a success because, after the initial responses for Prompt one and two, students gradually learned to use both languages.

Initially, students lifted answers from the prescribed Tourism texts and did not write in their own language. They found writing in English only easier than writing the response in both languages, which demanded comprehension of the content read. As more students wrote in both languages (Prompt three to ten), more responses were approved as relevant by the Tourism lecturer. For example, in Prompt nine, 15 students participated and 14 shuttled between English and isiXhosa in their responses; only one using English exclusively. All 15 responses were relevant, according to the Tourism lecturer, including 
the one written in English only. Students who were on the website regularly and participated in all the prompts saw improvements in their writing.

For example, to respond to Prompt nine ('Explain how the following can influence a consumer's buying behaviour: age, marital status and education background'), part of a regularly participating student's (Xhama) answer was:

Age: People buy different goods and services over a life time. People's tastes in clothes, furniture, and recreation is also age related. [Izinto ozithengayo ziya zitshintsha as uba umntu ekhula. Abantu bathenga izinto based on iminyaka yabo. Abathengi bademanda products ezahlukeneyo kunye neservices zixhomekeke kwiminyaka yabo.]

[Goods that one buys change as one grows. People buy goods based on their age. Buyers demand different products and services according to their age.]

Marital Status: Married couples especially those without children have satisfactory incomes and buy durable products such as cars, luxury goods and household appliances. [Abantu abatshatileyo abanabantwana bona bazi biggest group of home buyers, bana low liquid assets kwaye basenokungonwabi kwicala lemali ngoba kaloku bona kufuneka bethenge ukutya kwabantwana, amayeza, izinto zesikolo kunye nempahla.]

[Married couples with children on the other hand, are the biggest group of home buyers, they have low liquid assets and they might not be happy financially because they have to buy food for their children, medicines, stationery and clothes.]

Education background: Educated consumers have a strong influence on consumer decisions because of their skills, knowledge and personality. [Abantu abafundileyo ngabona bantu bakwaziyo ukuinfluencer abantu abangafundanga kuloproduct ithengiswayo kwaye bayafikeleleka xa ufuna ulwazi oluphangaleleyo. Bayakwathanda ukuthenga izinto ezikwixabiso eliphezulu kuba barhola imali ezikwaziyo ukumeeta zonke I needs zabo (Xhama).]

[Educated people are the ones who are able to influence those that are uneducated to buy a product which is currently on sale. They are also approachable when one needs more information, they like to buy expensive products because they earn salaries that enable them to meet their needs.]

According to Canagarajah (2011: 403) code meshing not only treats the languages as part of a single integrated system, but also accommodates the possibility of mixing communicative modes and diverse symbol systems, other than language. The layout in Xhama's response is a mode (Lea \& Street, 2006: 371) that can be learned by others as it is useful for the response to be read easily, although it is not language. For example, Xhama highlights the topic (Education background) and separates it with a colon from the explanation. From the beginning, the reader knows what she is writing about. She writes separate paragraphs for how "age" and "marital status" influence a consumer's buying behaviour. 
Regular reading of Tourism texts improved their discussions online, which improved their writing. For example, compare Xhama's first response in Prompt one to her response for Prompt nine. This shows that Xhama's writing literacies were improving. In Prompt one, when asked what makes South Africa a tourist attraction and whether tourism in the country was able to create employment and having to discuss three ways in which tourism could create employment in South Africa, Xhama's response was as follows:

- in Hospitality

- Travel Sector

- Tourism Industry

While she was asked to discuss, she listed subheadings in her answer. But, her response to Prompt nine (see above) highlighted the subheadings and discussed them. That shows improvement in her academic writing.

This improvement was noticed in other students' responses as well. Students found writing academic essays difficult at the beginning of the year. Nonji wrote in her reflective journal:

"Writing an essay has always been fun to me...Writing an essay is becoming complicated and I am not finding it fun and easy to write it at this point in time".

(Extracted from Nonji's reflective journal)

Nonji's academic writing (assignment) marks were: 47, 73 and 74. Although academic writing was difficult for her, it had improved by the end of the year.

The literacy practices in the tutorial adopted the culturally sensitive view of the ideological model of literacy, for instance, when students were code meshing online (Street, 2003: 77). Code meshing online provided students with a more flexible opportunity to use their multilingual repertoires as they were not under the supervision of the tutor in the computer labs. This process is advocated by Street (2003: 77) when he explains that literacy practices differ from context to context (from discipline to discipline, in this case). The classroom tutorial context differed from the online tutorial (code meshing) in the computer laboratory context, where students code meshed at different times and at their own pace. It is clear from students' responses that they needed more time to practise the strategy to learn to respond to each other's writing online, as they initially only answered the prompts and did not respond to each other according to their instructions. Their reluctance to code mesh initially resembled the student Buthainah in Canagarajah's study (2011: 404), who gauges the communicative context to determine if she could code mesh in that writing project. Students in this study were at first not sure if they would be penalised for using isiXhosa in academic writing. Consequently, only one student used both English and isiXhosa to respond to the first prompt. She also separated the languages.

For Prompt five, students had to explain the relationship between leisure, recreation and tourism. The researcher observed that Ndavi first wrote the concepts to be explained in English and then gave the answer in her home language. This could show that Ndavi 
knew the meanings of the concepts, in both languages, but not the concepts. For example, she wrote:

...Leisure: izinto esizenzayo kwi xesha lethu apho singasebenzi ngalo okanye loku phumla emisebenzini yethu sonwabe. Recreation: yimidlalo eyenziwa ngexesha umntu angasebenzi ngalo. Tourism: kukuhamba-hamba uhlale ezindaweni ezifana nehotela, B\&B nezinye, uhambela ulonwabo, umsebenzi nezinye izinto (Ndavi).

[Leisure: Are things we do to be happy when we are not working or when we are not at work. Recreation: Is sport people participate in when they are not working. Tourism:Is travelling and staying in places like hotels, $B \& B$ and others, travelling just for enjoyment, work and other things.]

Canagarajah's (2011: 403) argument that code meshing accommodates the mixing of communicative modes is clear in the students' responses to Prompt five, as some students wrote the concepts in bold or italics and/ or underlined to indicate importance of the word in comparison to others in a sentence. Highlighting by underlining or writing in bold is not language, but are symbols used for concepts (in this case) to stand out, compared to the explanation in the response. Thus, Ndavi was code meshing, as she was alternating languages (English and isiXhosa) and going beyond that by mixing modes and symbols.

In Prompt seven, the question demanded knowledge and understanding of the concept "sustainable development" ("What is the meaning of sustainable development?"). Students had already learned about this concept during bilingual glossary development in the tutorial. So, most students understood its meaning in both English and isiXhosa. For example, Tabs wrote:

Xa kuthethwa ngeSustainable Development kuthethwa ngokusetyenziswa nangokuphathwa kwezinto zemveli ezifana nemithi okanye iintyatyambo, umhlaba, amanzi kunye nezilwanyana ekuphuculeni nasekufezekiseni iimfuno zabantu. Kodwa ngendlela elungileyo apho khona nolutsha olusezayo nolusezakubakho lungakwazi ukuzisebenzisa nalo ekufezekiseni iimfuno kunye nezidingo zablo.

[Sustainable Development means sustainable development that meets the needs of the present without compromising the ability of future generations to meet their own needs.] (Tabs).

Tabs explained the concept in detail in both languages and his understanding of it cannot be doubted.

Some English explanations seemed to have been copied word-for-word from a source, or memorised, as all students had the exact same answers. However, for the isiXhosa explanations of the concept, a variety of words was offered, although the answer was the same. IsiXhosa answers were sometimes long and the concept was explained in detail, showing full understanding (See Tabs' response above). This could be a sign that the 
concepts do not exist in the students' home language. English explanations were mostly brief, for those students who separated the languages in their answer.

In descriptions given of "sustainable development", it was easy to distinguish between students who understood the meaning of the concept and those who had memorised without understanding. In the latter case, the definition was correct in English, but students could not interpret it in isiXhosa, although they had studied isiXhosa to Grade 12 level at school. Instead, they would give vague interpretations and sometimes irrelevant examples. These students were careful not to mesh languages in their explanation of the concept, as they seemingly did not want to spoil the memorised answer. They also seemed afraid of violating the grammatical rules of both languages, therefore separating the languages, as demonstrated below:

Sustainable tourism refers to development that meets the needs of the present with compromising to the needs of the future generation. [Uphuhliso olukhawulelana nemfuno zabantu bangoku ngaphandle koku khawulela nemfuno zabantu abasezayo (Ngulo).]

[Development that meets the needs of the present people without meeting those of the future generation.]

The isiXhosa version of the answer is vague, as the government cannot meet the demands of the future generation, but can only safeguard them. The student seemed to remember some of the words for this definition in English, while others were forgotten, which makes even the English definition of the concept vague.

In the example below, the student seemed to have copied the answer from a text and had included unnecessary parts. Seemingly, the student knew the answer was in that paragraph, but could not select it.

The concepts of needs, in particular the essential needs of the world's poor, to which overriding priority should be given. The Idea of limitations imposed by the state of technology and social organizations on the environment's ability to meet present and future needs. In total sustainable development meets the needs of the present without compromising the ability of the future generations to meet their own (Mtande).

From students' online responses, the Tourism lecturer could identify students who did not understand the meaning of the concepts and would revise the concepts with them in class.

In Prompt seven, students who had learned through code switching and translanguaging up to Grade 12 seemed to provide more acceptable answers in both languages. For example, Ngqambs, from the former Transkei, wrote:

Sustainable development means using the natural resources effectively and efficiently but not to forget the needs of the future generation. e.g the use of phelomon animals. [Sustainable development- 
kukusetyenziswa kwezinto ngohlobo olunonophileyo khona ukuze zingapheli nakwixetsha elizayo e.g amanzi \& plants (Ngqambs).]

[Sustainable development is the management of resources in such a way that they can also be used in future e.g. water \& plants.]

This answer, although with distracting language, shows full understanding of the concept and does not seem to have been memorised or copied, as the student uses his own words. While the languages are separated, he used the home language to confirm his understanding, as the isiXhosa part of the answer clearly provides an acceptable answer for the question. Some answers were brief while languages were used simultaneously as in translanguaging:

I sustainable development yi development ehlangabezana ne needs ze present generation without compromising imfuneko ze future generation.

[Sustainable development is development that meets the needs of the present generation without compromising those of the future generation.]

When students read the Tourism texts and discussed them through code switching and translanguaging, they learned terms and concepts in English and isiXhosa. This helped those who did not understand them during reading. Usually, those who had studied Tourism at high school played an important role in helping others with clarifications.

Results from this research clearly indicate that, while other factors cannot be ruled out, code meshing too contributes to improving academic writing. It provides students with a multilingual space to discuss the content they learn in writing, using their linguistic repertoires. Students practise and learn how to write paragraphs from others in the online space, while language is not a barrier as they can use their languages alternatively. In this study, their reading literacies also improved as they had to read about a new topic weekly, understand it and respond to questions online. Thus, reading and writing, which are the most important academic literacies in higher education, can be improved through the use of code meshing.

\section{REFERENCES}

BLOMMAERT, J, J COLLINS \& S SLEMBROUCK, S. 2005. Spaces of multilingualism. Language \& Communication 25:197-216.

BRYMAN, A. 2009. Handbook of data analysis. SAGE: Los Angeles.

CANAGARAJAH, S. 2006. The place of world Englishes in composition: Pluralization Continued. College Composition and Communication, 57(4):586-619.

CANAGARAJAH, S. 2007. Multilingual academic literacies: Pedagogical foundations for code meshing in primary and higher education. Journal of Applied Linguistics, 4(1): 55-77.

CANAGARAJAH, S. 2011. Code meshing in academic writing: Identifying teachable strategies of translanguaging. The Modern Language Journal, 95(3):401-417.

CENOZ, J. 2009. Towards multilingual education. Bristol, England: Multilingual Matters. 
CENOZ, J \& D GORTER. 2011. Focus on multilingualism: A study of trilingual writing. The Modern Language Journal, 95(11): 356-369.

CENOZ, J \& D GORTER. 2011. A holistic approach to multilingualism education: Introduction. The Modern Language Journal, 95(11): 339-343.

CREESE, A \& A BLACKLEDGE. 2010. Translanguaging in the bilingual classroom: A pedagogy for learning and teaching? The Modern Language Journal, 94(10): 103115.

GARCIA, O, L BARTLETT \& J KLEIFGEN. 2007. From biliteracy to pluriliteracies. In Auer, $\mathrm{P} \& \mathrm{~L}$ Wei, (eds.). Handbook of Multilingualism and Multilingual Communication. Berlin: Mouton de Gruyter.

GARCIA, O \& C LEIVA. 2014. Theorising and enacting translanguaging for social justice. In Blackledge, A \& A Creese (eds.). Heteroglossia as Practice and Pedagogy. Dordrecht: Springer Netherlands. Pp. 199-216.

HORNBERGER, NH. 2004. The continua of biliteracy and the bilingual educator: Educational linguistics in practice. International Journal of Bilingual Education and Bilingualism 7(2/3): 155-171.

LEA, MR \& B STREET. 2006. The "academic literacies" model: Theory and applications. Theory into Practice, 45(4): 368-377.

MAKALELA, L. 2013. Translanguaging in kasi-taal: Rethinking old language boundaries for new language planning. Stellenbosch Papers in Linguistics Plus, 42: 111-125.

MARTIN-JONES, M \& K JONES. (eds.) 2000. Multilingual Literacies. Philadelphia, PA: John Benjamins.

PAXTON, MIJ. 2009. It's easy to learn when you are using your home language, but with English you need to start learning language before you get to the concept: Bilingual concept development in an English medium university in South Africa. Journal of Multilingual and Multicultural Development, 30(4): 345-359.

RUIZ, R. 1984. Orientations in language planning. NABE Journal 8 (2) 1984.

STREET, B. 1993. Cross-cultural approaches to literacy, Vol. 23. Cambridge, UK: Cambridge University Press.

STREET, B. 2003. What's "new" in new literacy studies? Critical approaches to literacy in theory and practice. Current Issues in Comparative Education, 5(2): 77-91.

VALESCO, P \& O GARCIA. 2014. Translanguaging and the writing of bilingual Learners. Bilingual Research Journal, 37(1): 6-23.

\section{BIOGRAPHICAL NOTE}

Thoko Batyi works in the Centre for Teaching, Learning and Media (CTLM) at Nelson Mandela Metropolitan University as an academic developer and a Language Development Professional. She studied in the department of Applied Language Studies and specialises in academic literacies and multilingualism in higher education teaching and learning.

Email: Thoko.batyi@nmmu.ac.za 